\title{
Article \\ Compact Carbon-Based Membrane Reactors for the Intensified Anaerobic Decolorization of Dye Effluents
}

\author{
Mohammad Shaiful Alam Amin ${ }^{1,2}\left(\right.$, Frank Stüber ${ }^{1}$, Jaume Giralt ${ }^{1}\left(\mathbb{D}\right.$, Agustin Fortuny $^{3}{ }^{(}$, Azael Fabregat $^{1}(\mathbb{D}$ \\ and Josep Font ${ }^{1, *}$ D \\ 1 Departament d'Enginyeria Química, Universitat Rovira i Virgili, Av. Països Catalans 26, \\ 43007 Tarragona, Spain; mohammad.amin@urv.cat (M.S.A.A.); frankerich.stuber@urv.cat (F.S.); \\ jaume.giralt@urv.cat (J.G.); azael.fabregat@urv.cat (A.F.) \\ 2 Department of Chemical Engineering and Polymer Science, Shahjalal University of Science and Technology, \\ Sylhet 3114, Bangladesh \\ 3 Departament d'Enginyeria Química, Universitat Politècnica de Catalunya, EUPVG, Av. Víctor Balaguer, s/n, \\ 08800 Vilanova i la Geltrú, Spain; agustin.fortuny@upc.edu \\ * Correspondence: jose.font@urv.cat; Tel.: +34-977-559646
}

Citation: Amin, M.S.A.; Stüber, F.; Giralt, J.; Fortuny, A.; Fabregat, A.; Font, J. Compact Carbon-Based Membrane Reactors for the

Intensified Anaerobic Decolorization of Dye Effluents. Membranes 2022, 12, 174. https://doi.org/10.3390/ membranes12020174

Academic Editor: Petros Samaras

Received: 31 December 2021

Accepted: 28 January 2022

Published: 1 February 2022

Publisher's Note: MDPI stays neutral with regard to jurisdictional claims in published maps and institutional affiliations.

Copyright: (c) 2022 by the authors. Licensee MDPI, Basel, Switzerland. This article is an open access article distributed under the terms and conditions of the Creative Commons Attribution (CC BY) license (https:// creativecommons.org/licenses/by/ $4.0 /)$.

\begin{abstract}
Carbon-based membranes integrated with anaerobic biodegradation are presented as a unique wastewater treatment approach to deal with dye effluents. This study explores the scope of ceramic-supported carbon membrane bioreactors (B-CSCM) and ceramic-supported graphene oxide membrane bioreactors (B-CSGOM) to decolorize azo dye mixtures (ADM) and other dyes. The mixture was prepared using an equimolar composition of monoazo Acid Orange 7, diazo Reactive Black 5, and triazo Direct Blue 71 dye aqueous solution. Afterwards, as in the ADM experiment, both compact units were investigated for their ability in the biodecolorization of Methylene Blue (MB) and Rhodamine B (RhB) dye solutions, which do not belong to the azo family. The obtained outcomes revealed that the conductive surface of the graphene oxide (GO) membrane resulted in a more efficient and higher color removal of all dye solutions than B-CSCM under a wide feed concentration and permeate flux ranges. The maximum color removal at low feed concentration $\left(50 \mathrm{mg} \cdot \mathrm{L}^{-1}\right)$ and permeate flux $\left(0.05 \mathrm{~L} \cdot \mathrm{m}^{-2} \cdot \mathrm{h}^{-1}\right)$ was $96 \%$ for ADM, $98 \%$ for MB and $94 \%$ for $\mathrm{RhB}$, whereas it was $89 \%, 94 \%$ and $66 \%$, respectively, for B-CSCM. This suggests that the robust, cost-effective, efficient nanostructures of B-CSGOM can successfully remove diverse azo dye solutions from wastewater better than the B-CSCM does.
\end{abstract}

Keywords: anaerobic decolorization; dye effluents; graphene oxide membrane; matrimid membrane

\section{Introduction}

Dye molecules are widely applied for coloring in various sectors such as the textile, pulp and paper, leather, drug, food and cosmetics industries. Their use has increased rapidly in recent decades, resulting in massive discharges of toxic, mutagenic, carcinogenic and mostly recalcitrant dye effluents into the environment [1]. The presence of this dyestuff waste in industrial effluent has a detrimental effect on the ecosystem, the human body and animals [2]. The dyed waste turns the color of the water into an unpleasant hue that negatively impacts the photosynthesis process and the amount of dissolved oxygen in aquatic life [3,4]. Moreover, dye-containing wastewater makes water sources unsuitable for drinking and for household and industrial purposes [5]. As a result, developing a simple, economical and sustainable wastewater treatment for removing dye-containing effluent from the environment is considered a critical issue.

At present, several physical, chemical and biological wastewater treatment methods such as adsorption, photocatalysis, coagulation, electrocoagulation, advanced oxidation, ozonation, filtration processes and membrane bioreactors have been examined extensively [6-8]. Since most dyestuff molecules are chemically stable and notably soluble 
in water, it is difficult to remove them using the traditional treatment process $[9,10]$. In addition, most of these treatment procedures become less appealing due to the higher installation and operating cost, moderate efficiency, duration of the treatment and evolving secondary pollution $[11,12]$. What is more, this secondary solid waste might be toxic in nature and poses additional environmental problems associated with sludge treatment and disposal. The dye removal process using a membrane is one of the most convenient and cost-effective applications. Membrane units are capable of overcoming some of the previously described limits, such as reduced equipment size, lower energy usage and lower capital costs $[13,14]$. Additionally, they may eliminate the need for chemicals, making them an environmentally friendly and accessible choice. Among the membrane separation processes, ultrafiltration and nanofiltration are the most used for dye removal; however, fouling limits the membrane flux as well as its performance [11]. In recent years, reverse osmosis (RO) filtration followed by ultrafiltration or nanofiltration has proven effective in removing dye molecules; nevertheless, installation cost remains a significant challenge for its wide application. Electrodialysis and ion-exchange membranes, on the other hand, are also tested for the treatment of water and wastewater.

Due to their effective performance when addressing suspended solids, color and high Biochemical Oxygen Demand (BOD) loads, biological treatment processes are widely used in Wastewater Treatment Plants (WWTPs). These processes can occur in the presence or absence of oxygen (aerobic and anaerobic conditions, respectively). Compared to aerobic treatment, anaerobic biodegradation is a simple and less expensive azo dye decolorization approach [15]. However, in this process, the electron transport between the microorganisms and the dye molecules become the limiting steps that reduce the biodegradability and increase the residence time. Therefore, when searching for an environmentally friendly treatment process for decolorizing dyes from wastewater, it seems that the combination of anaerobic biodegradation and membrane separation processes would be perfectly complementary.

Most of the materials employed for membrane separation used in wastewater treatment are essentially non-conductive in nature [16]. However, a faster electron transfer mechanism in the anaerobic dye reduction is the crux for an effective treatment method [17]. Daniela et al. $[18,19]$ reported that conductive graphene-based composite ion-change membranes could be used for wastewater treatment purposes. Nonetheless, they may not be feasible in terms of cost, which could cause incompetence for large-scale operations with practical applications. Therefore, besides the good mechanical and chemical stability, carbon-based membranes exhibit a conductive layer on the top of their surface that can be integrated with the anaerobic process for dye decolorization [20,21]. Carbon membranes are usually derived from the carbonization of organic polymer materials such as polyimide, cellulose, melamine, polyethersulfone, polyacrylonitrile and the like, in an inert atmosphere [22,23]. A nanostructured carbon membrane for wastewater treatment shows thermally and electrically conductive properties synthesized by graphitic oxide and carbon nanotubes [24,25]. In our previous work, we synthesized two types of ceramic-supported carbon membranes [21,26]. One of the membranes was fabricated by the carbonization of Matrimid 5218 and another one by the vacuum filtration of exfoliated graphene oxide solution. Notably, both the Ceramic Supported Matrimid Membrane (CSCM) and the Ceramic Supported Graphene Oxide Membrane (CSGOM) displayed good electron conductivity that integrated the membrane separation with the anaerobic biodegradation to achieve a successful azo dye decolorization process.

To the best of our knowledge, it is the first time that the removal of azo dye mixture (ADM), phenothiazine Methylene Blue (MB) and sticky fluorescence Rhodamine B $(\mathrm{RhB})$ solutions were conducted in an integrated membrane filtration with an anaerobic biodegradation process. For this, two compact membrane bioreactors using carbonized Matrimid and graphene oxide membranes were studied to decolorize the dye molecules. These two carbon-based membranes were compared to select a more suitable configuration for the anaerobic biodecolorization of azo dye wastewater. Throughout the experiments, 
the decolorization rate of dye solution was examined under several feed concentrations and permeate fluxes.

\section{Materials and Methods}

\subsection{Fabrication of Ceramic-Supported Carbon Membrane}

The carbon-based membranes were synthesized from several membrane precursors to compare their suitability for the biodecolorization of dyestuff molecules. For this purpose, two membranes were prepared over porous ceramic support $\left(\mathrm{ZrO}_{2}-\mathrm{TiO}_{2}\right.$ microfiltration flat element, diameter: $47 \mathrm{~mm}$; thickness: $2.5 \mathrm{~mm}$; molecular weight cut-off: $50 \mathrm{~kg} \cdot \mathrm{mol}^{-1}$; TAMI Industries, Nyons, France) using either a 10\% wt. of Matrimid 5218 (Huntsman Advanced Materials, The Woodlands, TX, USA) in NMP (1-methyl-2-pyrrolidone, Sigma Aldrich, ref. 328634, Madrid, Spain), or a $1 \mathrm{mg} \cdot \mathrm{mL}^{-1}$ graphene oxide solution, respectively. In CSCM, the polymeric solution was deposited on the support by a two-step spin coating method. After $24 \mathrm{~h}$ of drying, the carbon membrane was finally formed by carbonizing it at $800{ }^{\circ} \mathrm{C}$ under an inert atmosphere [21]. For the other carbon-based membrane (CSGOM), the exfoliated graphene oxide solution was prepared by the modified Hummer method using $20 \mu \mathrm{m}$ of pristine graphite powder (Sigma Aldrich, ref. 282863, Madrid, Spain) [27]. The porous graphene oxide layer was deposited over the ceramic support by vacuum-assisted filtration of 3-5 mL of $1 \mathrm{mg} \cdot \mathrm{mL}^{-1}$ graphene oxide solution using the filtration cell [26]. The desired thickness of the uniform GO layer was formed within $15 \mathrm{~min}$ of vacuum filtration. The membrane was subsequently dried at $80^{\circ} \mathrm{C}$ for $24 \mathrm{~h}$ and subsequently $100^{\circ} \mathrm{C}$ for $72 \mathrm{~h}$ to get a stable and robust CSGOM.

\subsection{Experimental Set-Up for Anaerobic Biodegradation}

Anaerobic biodecolorization of the dyestuff molecule by carbon-based membrane bioreactor (B-CSCM and B-CSGOM) process is depicted in Figure 1. Nitrogen gas (Purity $>99.99 \%$, Linde, Valencia, Spain) flowed in the feed tank to pump the feed solution to the two membrane bioreactors and modulated the permeate flux by changing the transmembrane pressure (TMP). In addition, it was used to maintain the anaerobic conditions throughout the decolorization process. Thus, the entire system achieves a negative redox potential that forces the suitable conditions for the action of anaerobic microorganisms [28]. The feed solution was composed of dye, Sodium Acetate (Sigma Aldrich, ref. 110191, Madrid, Spain), and basal media. The concentration of Sodium acetate was three times (1:3 molar ratio) higher than the dye in each feed solution. Depending on the test, three different types of feed solutions were used as synthetic feed. The first feed was an equimolar solution of monoazo AO7 (ACROS Organics, ref. 416561000, Geel, Belgium), diazo RB5 (Sigma Aldrich, ref. 306452, Madrid, Spain), and triazo DB71 (Sigma Aldrich, ref. 212407, Madrid, Spain). The second and third were the solution of Methylene Blue (Fluka, ref. 66720, Madrid, Spain) and Rhodamine B (Fluka, ref. R6626, Madrid, Spain), respectively. On the other hand were basal media with microelements $\left(\mathrm{mg} \cdot \mathrm{L}^{-1}\right)$ composed by $\mathrm{MnSO}_{4} \cdot \mathrm{H}_{2} \mathrm{O}(0.155)$, $\mathrm{CuSO}_{4} \cdot 5 \mathrm{H}_{2} \mathrm{O}(0.285), \mathrm{ZnSO}_{4} \cdot 7 \mathrm{H}_{2} \mathrm{O}(0.46), \mathrm{CoCl}_{2} \cdot 6 \mathrm{H}_{2} \mathrm{O}(0.26),\left(\mathrm{NH}_{4}\right)_{6} \mathrm{Mo}_{7} \mathrm{O}_{24}$ (0.285), $\mathrm{K}_{2} \mathrm{HPO}_{4}$ (21.75), $\mathrm{Na}_{2} \mathrm{HPO}_{4} \cdot 2 \mathrm{H}_{2} \mathrm{O}$ (33.40), $\mathrm{KH}_{2} \mathrm{PO}_{4}$ (8.50), $\mathrm{FeCl}_{3} \cdot 6 \mathrm{H}_{2} \mathrm{O}$ (29.06), $\mathrm{CaCl}_{2}$ (13.48) $\mathrm{MgSO}_{4} \cdot 7 \mathrm{H}_{2} \mathrm{O}$ (15.2), $\mathrm{NH}_{4} \mathrm{Cl}$ (190.90). All the analytical grade chemicals were purchased from Sigma Aldrich (Madrid, Spain) and dissolved in Milli-Q water (Millipore Milli-Q system, Molsheim, France). 


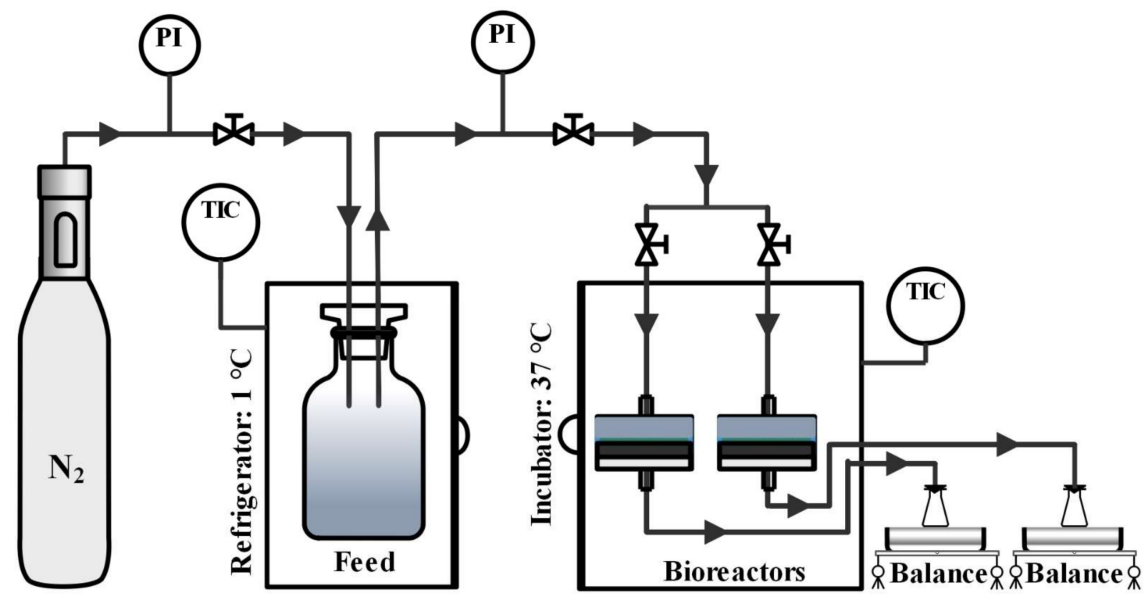

Figure 1. Experimental set-up for anaerobic decolorization of dye molecules by CSCM and CSGOM.

Temperature has a significant impact on decolorization performance and microbial population in this compact membrane bioreactor. Thus, the feed solution was kept at $1{ }^{\circ} \mathrm{C}$ to prevent microbial growth on the feed tank and maintain its actual dye and co-substrate (Sodium Acetate) composition. After placing $5 \mathrm{~mL}$ of secondary anaerobic sludge (collected from municipal WWTP Reus, Spain) over the carbon-based membrane, The membrane bioreactor, which was a direct-filtration cell (TAMI Industries, Nyons, France), was sealed tightly and then operated at $37 \pm 1{ }^{\circ} \mathrm{C}$ under constant flux dead-end filtration mode. At this temperature, the microbial strains are able to give the best biodecolorization rate [29].

\subsection{Membrane Characterization}

The Combined Focused Ion Beam-Scanning Electron Microscope (FIB-SEM, Scios 2 Dual Beam, Thermo Scientific, MA, USA) examined and compared the surface, crosssection and elemental composition of both CSCM and CSGOM. An Atomic Force Microscope (AFM) using Molecular Imaging Pico Plus 2500 (Bid Service, NJ, USA) examined the membrane surface and conductivity. Furthermore, chemical structures and microstructures of the carbon-based membranes were analyzed, respectively, through a Fourier Transform Infrared (FT-IR) spectrophotometer (FT/IR-6700, JASCO, Tokyo, Japan) and an X-ray Diffraction (XRD) diffractometer (Siemens D5000, Germany under the CuK $\alpha$ wavelength of $1.54056 \AA$ at $40 \mathrm{kV}$ and $30 \mathrm{~mA}$ ), respectively.

The filtration performance was assessed by means of membrane flux, pure water permeability (PWP) and hydraulic resistance, and calculated using Equations (1)-(3),

$$
\begin{gathered}
J=\frac{\Delta V}{\Delta t} \cdot \frac{1}{A} \\
\text { PWP }=\frac{J}{\Delta P} \\
H_{R}=\frac{\Delta P}{\mu} \cdot \frac{1}{J}
\end{gathered}
$$

where $J$ is the permeate flux $\left(\mathrm{L} \cdot \mathrm{m}^{-2} \cdot \mathrm{h}^{-1}\right), V$ is the volume of permeate $(\mathrm{L}), t$ the filtration time $(\mathrm{h}), A$ the membrane area $\left(\mathrm{m}^{2}\right), H_{\mathrm{R}}$ is the hydraulic resistance $\left(\mathrm{m}^{-1}\right), \Delta P$ is the transmembrane pressure (bar) and $\mu$ is the viscosity of the permeate corrected to the experimental temperature $(\mathrm{Pa} \cdot \mathrm{s})$.

The decolorization $(D)$ during the anaerobic bioreduction of the azo dye was measured using UV/VIS4000n Spectrophotometers (DINKO Instruments, Barcelona, Spain) and computed by Equation (4),

$$
D(\%)=\frac{A_{o}-A}{A_{o}} \times 100
$$


$A o$ and $A$ are the absorbance of feed and treated samples during the biodegradation process, respectively.

\section{Result and Discussion}

\subsection{Structural and Chemical Characterization of Ceramic-Supported Carbon Membranes}

The FTIR spectrum of carbon-based membranes shown in Figure 2 helps to reveal the presence of diverse functional groups, including carboxylic, hydroxyl, epoxy and imide, that also exhibited the appropriate molecular orientation. For the polymeric membrane and CSCM, before and after the carbonization of the membrane, the structural changes were observed through the transformation of the polymeric chains to the carbon membrane. The representative bands of the polymeric membrane (Matrimid 5218) were obtained at 1714 and $1360 \mathrm{~cm}^{-1}$, indicating the stretching of $\mathrm{C}=\mathrm{O}$ and $\mathrm{C}-\mathrm{N}$ groups [30]. The aromatic $\mathrm{C}=\mathrm{C}$ bending vibration, $\mathrm{C}-\mathrm{N}-\mathrm{C}$ transverse stretching and presence of $\mathrm{C}-\mathrm{H}$ aromatic monosubstituted benzene were found at 1501,1089 and $718 \mathrm{~cm}^{-1}$, respectively [31]. In the case of CSCM, compared to the initial polymeric membrane, no apparent bands were observed after its carbonization under a nitrogen atmosphere. This fact was similar to that observed by Sazali et al. [32], where they synthesized the Matrimid-based carbon membrane at different pyrolysis temperatures and polymeric compositions.

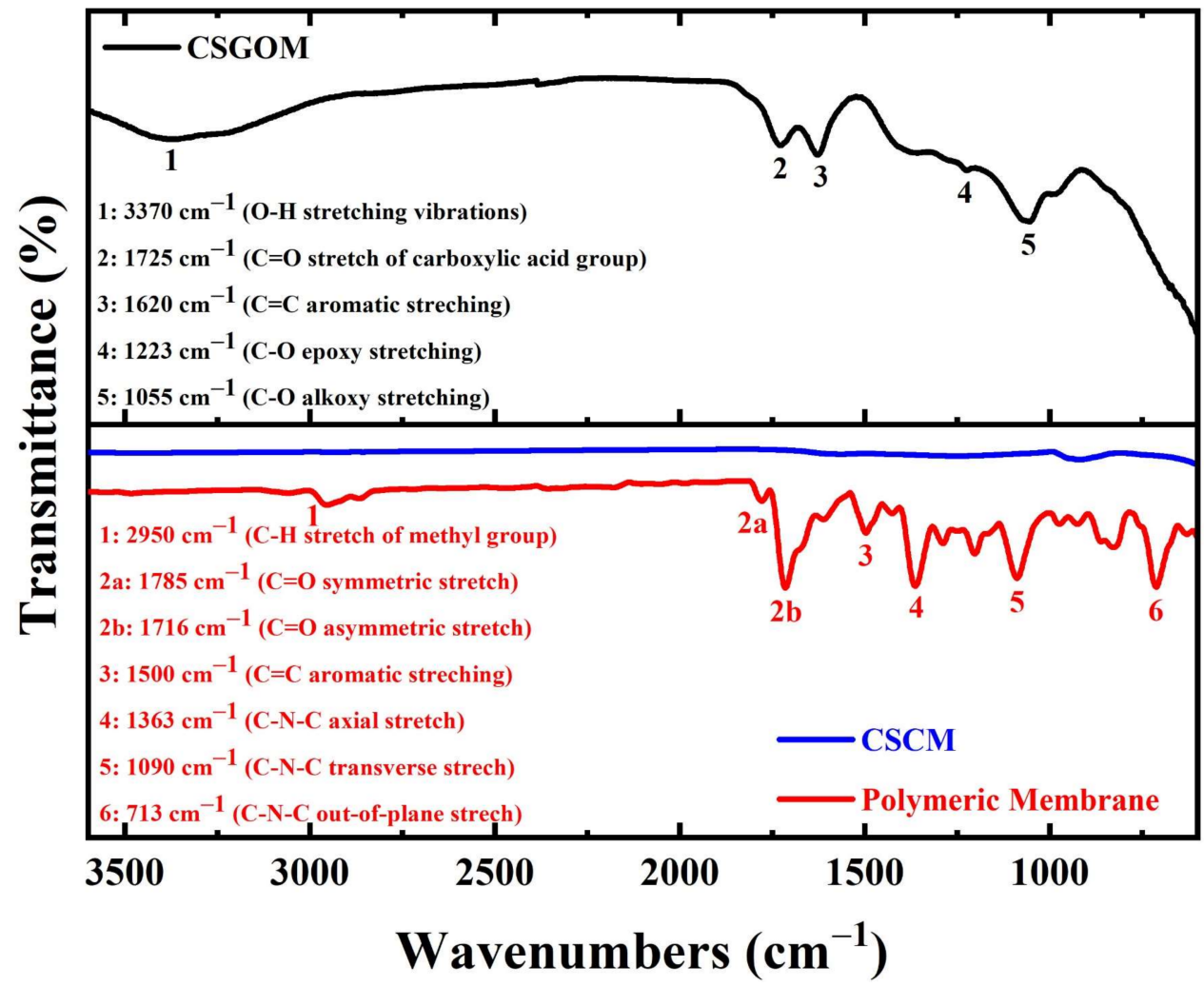

Figure 2. FTIR spectra of the polymeric membrane, CSCM and CSGOM (CSCM: 10\% wt. Matrimid and CSGOM: $1 \mathrm{mg} \cdot \mathrm{L}^{-1} \mathrm{GO}$ solution).

The peaks for numerous oxygen-containing functional groups, such as $\mathrm{O}-\mathrm{H}, \mathrm{C}=\mathrm{O}$ and $\mathrm{C}-\mathrm{O}$, were visible in the CSGOM spectra, which agrees well with earlier research and illustrates that the graphite exists mostly oxidized into GO [33,34]. In summary, the broad peak at $3370 \mathrm{~cm}^{-1}$ confirms the presence of hydroxyl groups on the GO layer of CSGOM while the peak at $1725 \mathrm{~cm}^{-1}$ indicates the $\mathrm{C}=\mathrm{O}$ stretching vibration of carboxylic acid positioned at the edge of the GO structure. The absorption peaks at 1620, 1223 and $1055 \mathrm{~cm}^{-1}$, respectively, were obtained due to the aromatic $\mathrm{C}=\mathrm{C}$ stretching, epoxy and alkoxy $\mathrm{C}-\mathrm{O}$ stretching vibration. 
The microstructure and interlayer distance of the ceramic support and ceramic supported carbon-based membranes were determined using XRD diffraction, as shown in Figure 3. In CS, CSCM and CSGOM diffractograms, identical peaks were obtained at $2 \theta=28,36,39,41,43,55$ and $57^{\circ}$ due to the presence of rutile, $\mathrm{TiO}_{2}$ [35], and $2 \theta=30,35$, 50,60 , and $63^{\circ}$ due to the presence of tetragonal $\mathrm{ZrO}_{2}$ [36], which is consistent with the information provided by the supplier of the ceramic support, consisting of layers of $\mathrm{ZrO}_{2}$ and $\mathrm{TiO}_{2}$. Furthermore, the diffraction peak located at $2 \theta=26.2^{\circ}$ is an indication that the CSCM consisted of highly graphitized carbon with an interlayer distance of $3.6 \AA$, which corresponds to the (002) plane of crystalline graphite [37]. In addition, the GO crystal plane (001) was clearly visible at $2 \theta=11.5^{\circ}$ (as shown in CSGOM diffractogram in Figure 3) with the interlayer spacing of $7.3 \AA$ that was larger than graphite atomic spacing [38]. The absence of a peak at $26.2^{\circ}$ means that all graphite molecules were completely oxidized to generate graphene oxide, and no graphitic contaminations were obtained [39]. This was expected as the oxygen-containing groups were attached to each layer edge to raise the spacing between the sheets, which aided GO exfoliation in the aqueous medium and increased the hydrophilicity [40].

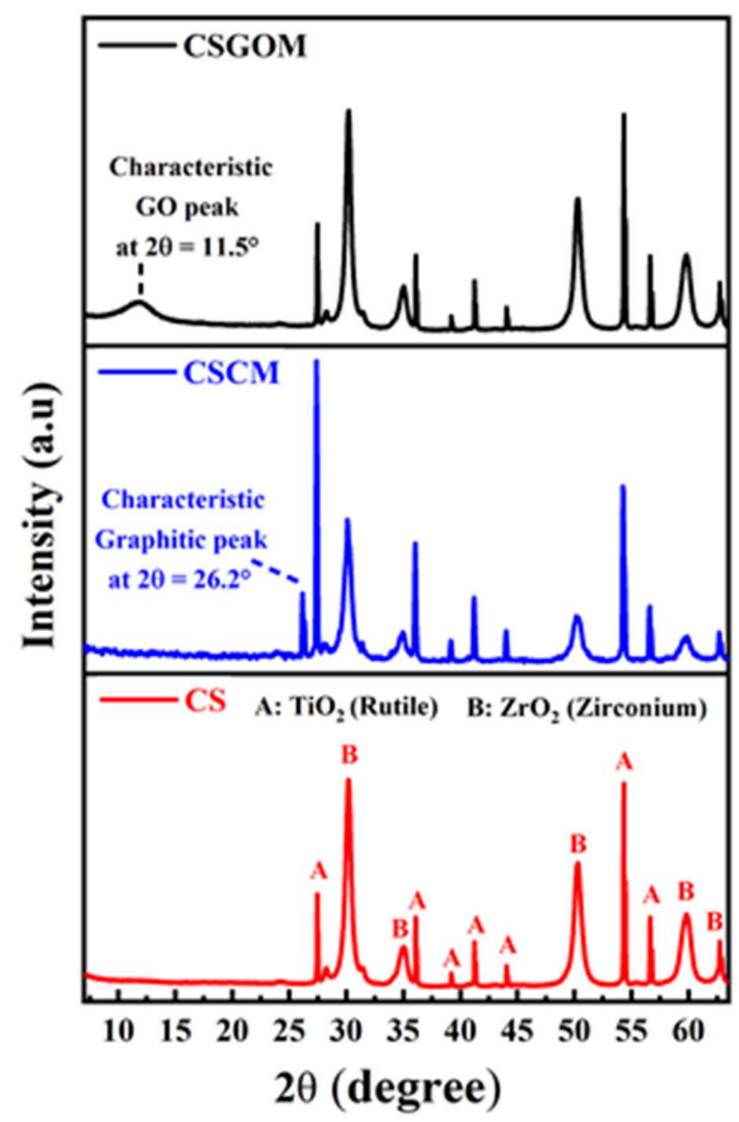

Figure 3. X-ray diffractogram of the ceramic support (CS) and the ceramic-supported carbon-based membrane (CSCM: $10 \%$ wt. Matrimid and CSGOM: $1 \mathrm{mg} \cdot \mathrm{L}^{-1} \mathrm{GO}$ solution).

The surface and cross-sectional views of the carbon-based membranes were studied using FESEM, which shows crucial morphological features for their application in the anaerobic decolorization process. As illustrated in Figure $4 a, b$, the top view of these carbon membranes clearly exhibits a defect-free smooth and porous carbon layer that was quite similar to previous studies [21,26]. The pore size of the resulting carbon membrane differed between the two alternatives. The difference between both membranes was the pore size and thickness of the respective synthesized carbon layers. The average pore size was found to be $35 \mu \mathrm{m}$ for CSCM and $20 \mu \mathrm{m}$ for CSGOM. On the other hand, the thickness was, respectively, 0.88 and $1.78 \mu \mathrm{m}$ for CSCM and CSGOM, as depicted in Figure 4c,d. The 
thinner layer in CSCM was due to the optimal spin coating method and high carbonization temperature maintained during the preparation of this membrane [41]. For the same reason, FESEM-EDX analysis observed higher carbon content in CSCM (64\%) than that of the CSGOM (49\%).
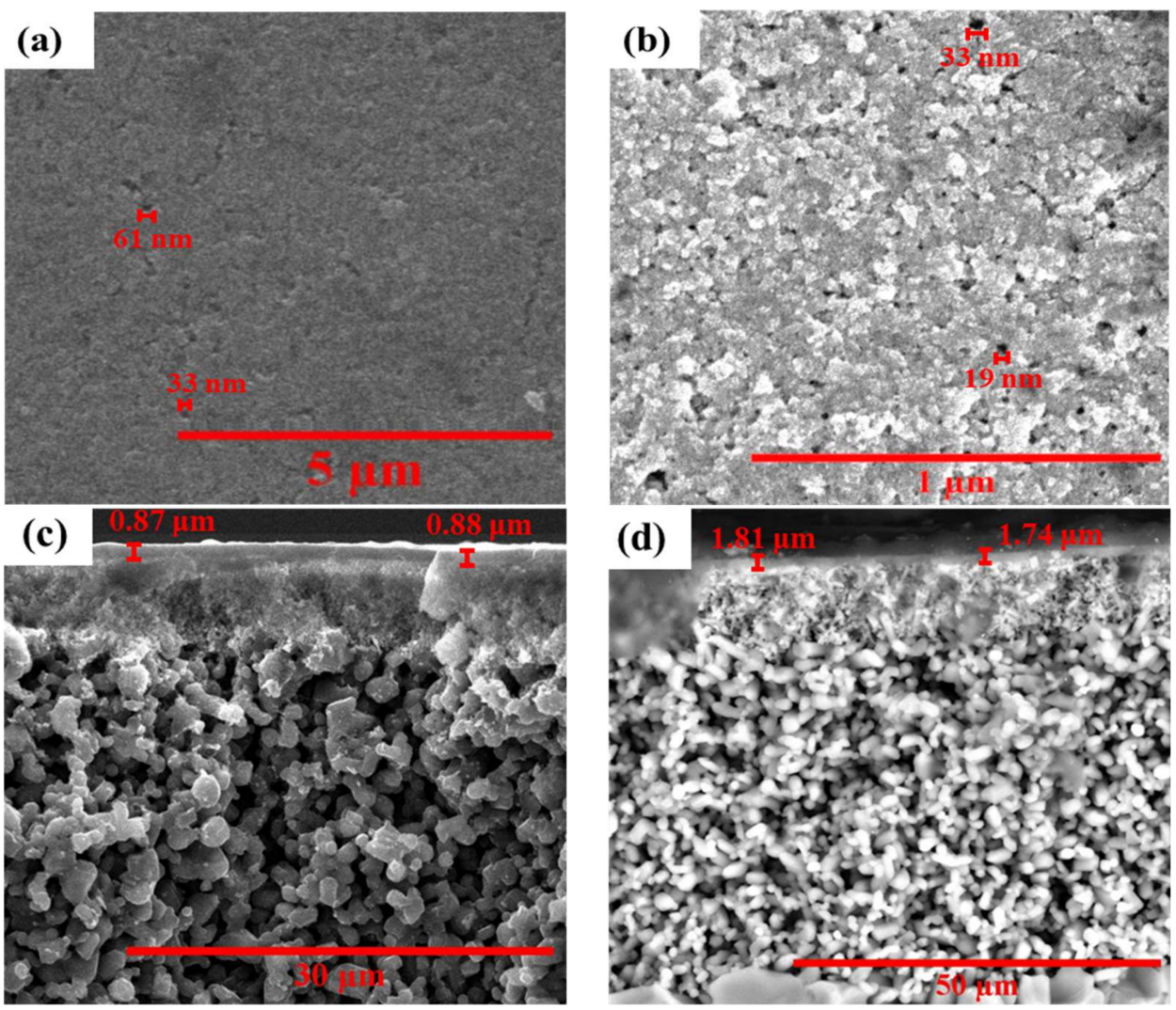

Figure 4. FESEM micrographs on the surface of (a,b) CSCM and CSGOM, and (c,d) cross section of CSCM and CSGOM (CSCM: 10\% wt. Matrimid and CSGOM: $1 \mathrm{mg} \cdot \mathrm{L}^{-1}$ GO solution).

The membrane surface roughness and conductivity were further investigated using AFM (at a random area of $5 \times 5 \mu \mathrm{m}^{2}$ ) and CSAFM (current sensing atomic microscopy) images. The 3D topography and current profile of these experiments are shown in Figure 5a-d. The root-mean-square (RMS) roughness of the carbon layer attained for the CSGOM surface was at $80.12 \mathrm{~nm}$, while the CSCM exhibited the lowest surface roughness at $32.94 \mathrm{~nm}$. This fact was attributed to the less porous structure of the carbonized Matrimid membrane, as shown by SEM images. This means a less porous structure but represents a smoother surface. In Figure $5 c, d$, the current distribution of the surface of the membrane was compared, and the local conductance on the graphene oxide membrane surfaces was found better than that of the CSCM. However, the rough conductive GO surfaces could improve the biodecolorization because of the more vigorous attachment of the biofilm to the surface and the intensified electron shuttle mechanism [42,43].

Therefore, it is possible to conclude from the above results that the compact membrane bioreactor made with a graphene oxide layer may be a more suitable solution for the dye bioreduction method. 
(a)
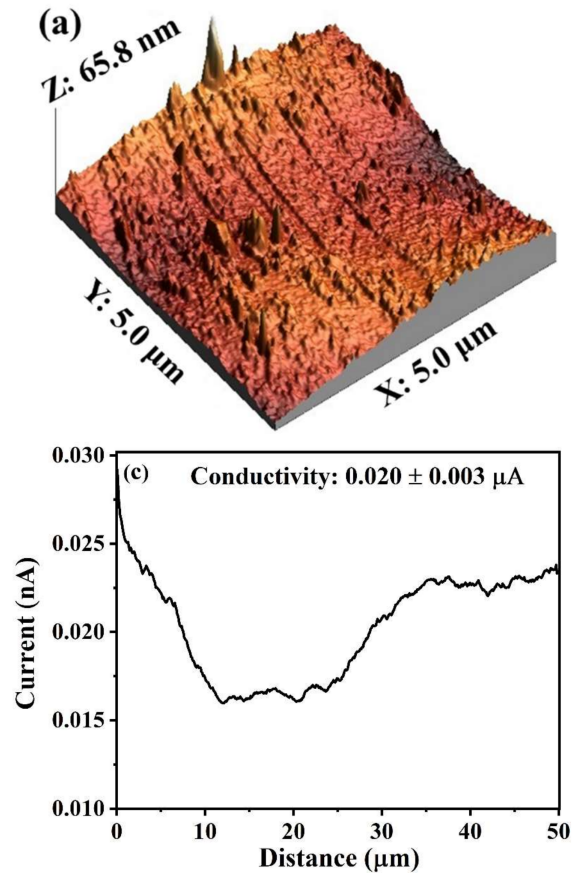

(b)
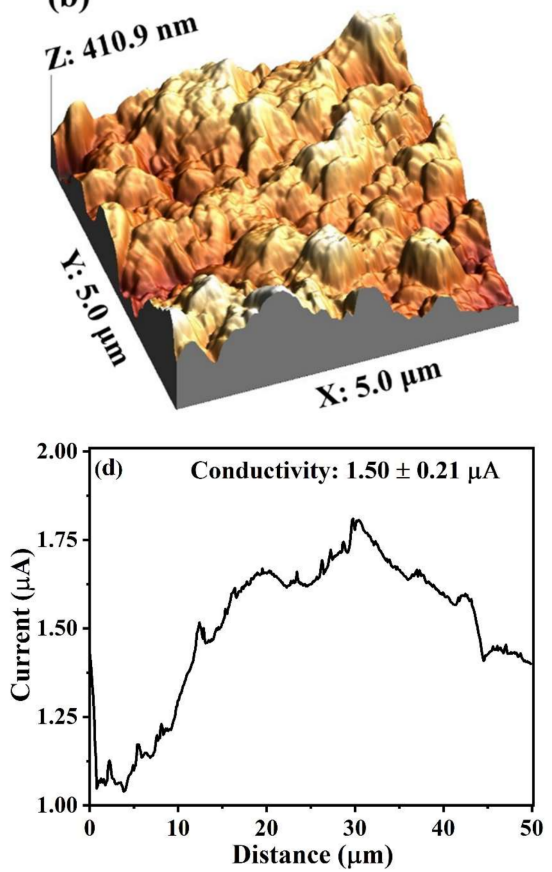

Figure 5. AFM images of CSCM and CSGOM (a,b) 3D Topography and (c,d) current distribution.

\subsection{Impact of the Carbonaceous Layer on Flux and Resistance}

The effect of membrane precursors (Matrimid 5218 or exfoliated GO solution) on filtration parameters such as permeate flux, pure water permeability (PWP) and hydraulic resistance $\left(H_{R}\right)$ was examined by experiment. Figure 6 displays the results of this comparative study, where the units were either the ceramic support (CS), CSCM (produced with $10 \%$ wt. of Matrimid solution) or CSGOM (made with $1 \mathrm{mg} \cdot \mathrm{mL}^{-1}$ of exfoliated GO solution). A simple comparison shows that the ceramic support gives the maximum permeate flux, $62.3 \mathrm{~L} \cdot \mathrm{m}^{-2} \cdot \mathrm{h}^{-1}$, and $77.8 \mathrm{~L} \cdot \mathrm{m}^{-2} \cdot \mathrm{h}^{-1} \cdot \mathrm{bar}^{-1}$ of PWP. At the same range of operating conditions, the lowest water flux $\left(10.2 \mathrm{~L} \cdot \mathrm{m}^{-2} \cdot \mathrm{h}^{-1}\right)$ and PWP $\left(12.9 \mathrm{~L} \cdot \mathrm{m}^{-2} \cdot \mathrm{h}^{-1} \cdot \mathrm{bar}^{-1}\right)$ were observed for CSGOM, which is less than $84 \%$ and $50 \%$, respectively, than for CS and CSCM. In addition, a bar chart depicting the hydraulic resistance of the CS, CSCM and CSGOM is shown at the bottom of Figure 6. Since both variables are directly related, CS displayed the lowest hydraulic resistance $\left(5.25 \pm 0.1 \times 10^{12} \mathrm{~m}^{-1}\right)$, while CSGOM has the highest.

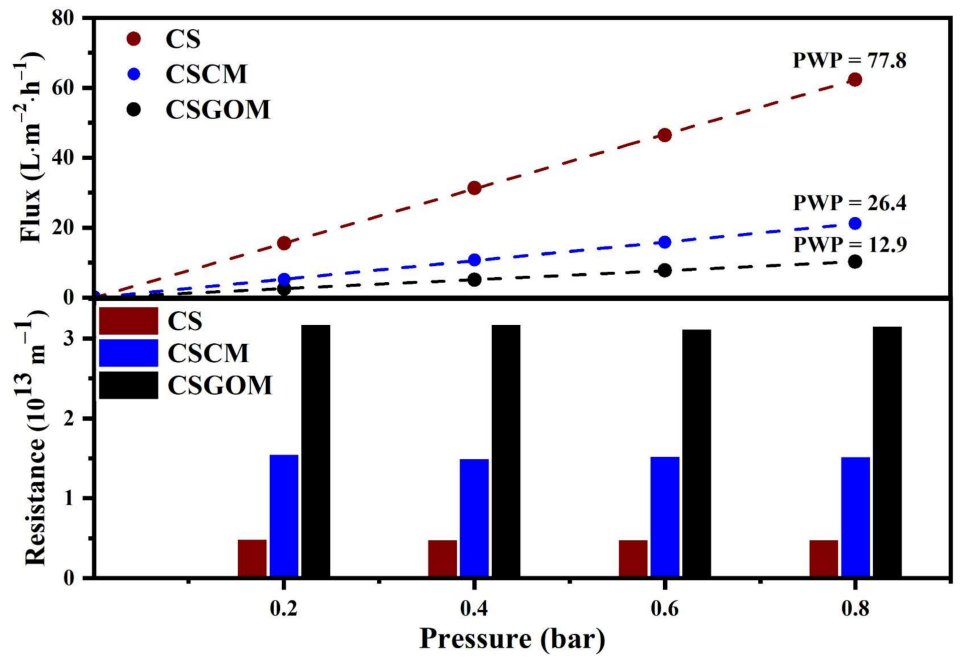

Figure 6. Variation of pure water flux, permeability, and resistance of CS, CSCM and CSGOM at $25^{\circ} \mathrm{C}$. CSCM: $10 \%$ wt. of Matrimid and CSGOM: $1 \mathrm{mg} \cdot \mathrm{mL}^{-1}$ of GO. 
Membrane thickness and pore size greatly influence the membrane performance by altering the permeate flux and hydraulic resistance [44]. In this study, in addition to the $\mathrm{TiO}_{2}-\mathrm{ZrO}_{2}$ layers of the ceramic support, we deposited an additional carbon layer on top of the support in each case. As a result, not only does the permeability of the membrane drops but the hydraulic resistance rises. Comparing the FESEM images of the two membranes synthesized over the ceramic support, the thickness of the defect-free carbon layer in CSCM was found to be smaller than that of CSGOM; on the contrary, the average pore size was relatively greater. Thus, the initial PWP $\left(77.8 \mathrm{~L} \cdot \mathrm{m}^{-2} \cdot \mathrm{h}^{-1} \cdot \mathrm{bar}^{-1}\right)$ and resistance $\left(5.25 \pm 0.1 \times 10^{12} \mathrm{~m}^{-1}\right)$ of the porous ceramic support changed after deposition of the carbonaceous layer. Due to the relatively larger thickness and smaller pore size of CSGOM than CSCM, PUP was recorded at $12.9 \mathrm{~L} \cdot \mathrm{m}^{-2} \cdot \mathrm{h}^{-1} \cdot \mathrm{bar}^{-1}$; on the other hand, in CSCM, it was $26.4 \mathrm{~L} \cdot \mathrm{m}^{-2} \cdot \mathrm{h}^{-1} \cdot \mathrm{bar}^{-1}$. Similarly, the hydraulic resistance rises to $1.50 \pm 0.2 \times 10^{13} \mathrm{~m}^{-1}$ in CSCM and $3.15 \pm 0.3 \times 10^{13} \mathrm{~m}^{-1}$ in CSGOM.

These results align with the trends observed by Sazali et al. [45], which indicated that the high carbonization temperature and precursor concentration were the keys for fabricating a thin carbon-based membrane. In the case of CSGOM, the membrane was prepared by vacuum-assisted filtration of an exfoliated GO solution with a concentration of $1 \mathrm{mg} \cdot \mathrm{mL}^{-1}$. The viscosity of the GO solution is much lower than that of Matrimid 5218, so it easily filled the internal ceramic support pore ( $\mathrm{GO}-\mathrm{ZrO}_{2}$ region) and then formed the mono or multilayer of GO on the top of CS. Due to internal blockage or filling of the support pore, the hydraulic resistance and permeability through the membrane were usually disrupted [46].

Our recent work demonstrated the selection of the most appropriate precursor is critical to achieving a porous, permeable carbon-based membrane $[21,26]$. In CSGOM, this is essential because the carbon layer thickness on the membrane surface increases as the GO concentration increases, resulting in a decrease in membrane flux [47]. Again, when the membrane is derived from a high precursor concentration $\left(>3 \mathrm{mg} \cdot \mathrm{mL}^{-1}\right)$, the GO layer can easily peel away from the surface or cause swelling of the layer [48]. On the other hand, GO membranes synthesized with low GO solution $\left(0.05-0.5 \mathrm{mg} \cdot \mathrm{mL}^{-1}\right)$ provide low carbon content that was not suitable for anaerobic biodecolorization application. A thicker and less porous GO layer was required to establish a defect-free GO layer with high carbon content and flux on CSGOM. Thus, compared to the CSGOM, pure water flux and permeability values were higher in CSCM. Since permeate flux and hydraulic resistance are interdependent, higher hydraulic resistance was observed in the CSGOM due to its lesser porosity and formation of $\mathrm{GO}-\mathrm{ZrO}_{2}$ layers inside the ceramic support.

\subsection{Role of the Membrane Precursors on Anaerobic Decolorization of Dye Molecules}

The combined effect of the filtration and anaerobic bioreduction of dye solutions in compact bioreactors was evaluated using carbon-based membranes (both CSCM and CSGOM) and ceramic support (CS). This study used $50 \mathrm{mg} \cdot \mathrm{L}^{-1}$ azo dye mixture (ADM) of feed solution that contained an equimolar mixture of the monoazo AO7, diazo RB5, and triazo DB71. All reactors were operated in dead-end filtration mode and maintained with a constant permeate flux of $0.05 \mathrm{~L} \cdot \mathrm{m}^{-2} \cdot \mathrm{h}^{-1}$. These concentrations in the feed solution were selected because they fall within the range owing to dye residues in industrial or textile wastewater, which is generally found between 10 and $50 \mathrm{mg} \cdot \mathrm{L}^{-1}$ [49]. In this test, the reactors operated with microorganisms are referred to as B-CS, B-CSCM, and B-CSGOM; in turn, reactors without microorganisms are labeled R-CS, R-CSCM, and RCSGOM, respectively. As illustrated in Figure 7, the simultaneous presence of the carbon layer and microorganisms has a significant effect on the bioreduction of ADM during the decolorization process. Both compact carbon-based membrane bioreactors, B-CSCM and B-CSGOM, gave very high decolorization rates under anaerobic conditions, with B-CSGOM achieving a maximum of $99 \%$ dye removal rate. 


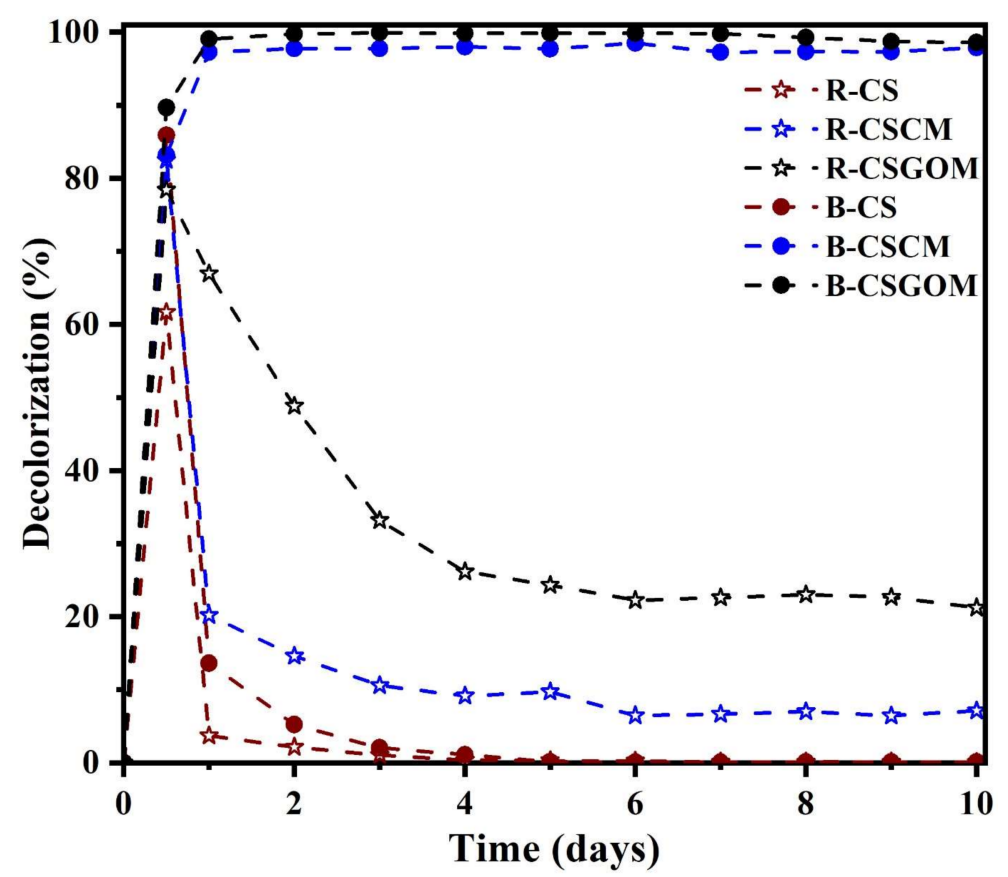

Figure 7. Decolorization of azo dye mixture in CS, CSCM and CSGOM reactors, and CS, CSCM and CSGOM bioreactors. Flux $=0.05 \mathrm{~L} \cdot \mathrm{m}^{-2} \cdot \mathrm{h}^{-1},[\mathrm{ADM}]_{\mathrm{o}}=50 \mathrm{mg} \cdot \mathrm{L}^{-1}$ and $\mathrm{T}=37^{\circ} \mathrm{C}$.

At the start of the anaerobic decolorization process, up to $12 \mathrm{~h}$, all the reactors accomplished more than $75 \%$ of the dye removal rate. Unlike the two carbon-based membrane bioreactors, the decolorization rate for all the other reactors progressively declined; it is noteworthy that, after $48 \mathrm{~h}$ of operation, the color removal for B-CS and R-CS dropped to almost zero. This strongly suggests that the dye was initially removed due to adsorption by the porous support and carbon membrane but, once saturated, they were not able to remove color anymore. Even though B-CS was used in conjunction with microorganisms, the color removal was negligible, too. It seems that the microorganisms were washed out from the reactor by the permeate flow because of the lack of nano-sized structure or support suitable to form a stable biofilm, as happens in the other carbon-based membranes. For CSGOM and CSCM, because of having a nanoporous carbon layer on the top, decolorization gradually decreased to reach a stable $20 \%$ for R-CSGOM and $6 \%$ for R-CSCM. In this case, the pore size of the carbonaceous layers was able to partially reject the dyes, although both the adsorption site and pore size decreased with the stream time [50]. The highest decolorization, 99\%, was observed for the bioreactor operated with CSGOM, while $97 \%$ of color removal was observed for B-CSCM. Overall, it means that the carbon layer derived from the carbonization of the Matrimid and graphene oxide has no adverse effect on bacterial growth for the successive formation of active biofilm [51-53]. As with the results obtained from the earlier ceramic-supported carbon-based membrane bioreactor experiments [21,26], these membranes perform triple roles in anaerobic dye decolorization. The carbon membrane served as biofilm support, redox mediator, and pollutant immobilizer that also retain the degradation products. In this way, the one-pass compact carbon-based membrane bioreactor has shown enhanced decolorization performance for azo dye mixtures.

Following each successful biodecolorization experiment, the membrane was cleaned using Milli-Q water backflushing. As a result, the initial permeate flux was regained without modifying the membrane properties, so it can be reused for subsequent color removal operation without any additional conditioning. 


\subsection{Biodecolorization Performance of CSCM and CSGOM}

After demonstration of stable and excellent performance by the carbon-based membrane bioreactors, the B-CSCM and B-CSGOM were investigated for long-term operation for the biodecolorization of structurally different dyes. Azo dye mixture, thiazine MB and fluoresce $\mathrm{RhB}$ dye solutions were examined under various permeate fluxes and feed concentrations. Initially, all compact reactors were run with $50 \mathrm{mg} \cdot \mathrm{L}^{-1}$ of dye solution at a permeate flux of $0.05 \mathrm{~L} \cdot \mathrm{m}^{-2} \cdot \mathrm{h}^{-1}$. After obtaining consistent decolorization, the system was left to operate for 10 days; then, the flow rate was first increased to $0.075 \mathrm{~L} \cdot \mathrm{m}^{-2} \cdot \mathrm{h}^{-1}$ and, finally, at 20 days, up to $0.1 \mathrm{~L} \cdot \mathrm{m}^{-2} \cdot \mathrm{h}^{-1}$. Similar procedures were repeated for compact bioreactors consisting of 75 and $100 \mathrm{mg} \cdot \mathrm{L}^{-1}$ of feed solution operated for the anaerobic decolorization of azo dyes.

Figure 8 collects all the decolorization performance data. Besides the influence of the feed concentration and permeate flow, it is shown that the biodecolorization effectiveness of different dye solutions widely depends on the number and nature of azo bonds and functional groups present in the dye structure. Apart from this, membrane properties, such as membrane precursors, pore size, and thickness, also played a relevant role in decolorization performance. It must be noted that all the dye decolorization removals decreased when feed concentration and permeate flux increased. In all experiments, the highest decolorization was achieved for the lowest feed concentration and permeate flow. Comparing again the performance of the bioreactors containing carbon-based membranes, B-CSGOM exhibits greater decolorization under all feed concentrations and fluxes. According to Figure 8, the maximum decolorization in the B-CSGOM system was $96 \%, 98 \%$, and $94 \%$ for ADM, $\mathrm{MB}$, and $\mathrm{RhB}$, respectively, (obtained for $50 \mathrm{mg} \cdot \mathrm{L}^{-1}$ of dye solutions at a permeate flux of $0.05 \mathrm{~L} \cdot \mathrm{m}^{-2} \cdot \mathrm{h}^{-1}$ ). On the contrary, the lowest decolorization was in B-CSCM experiments using $100 \mathrm{mg} \cdot \mathrm{L}^{-1}$ feed solutions and $0.10 \mathrm{~L} \cdot \mathrm{m}^{-2} \cdot \mathrm{h}^{-1}$ flow, which only achieved $84 \%$ for $\mathrm{ADM}, 84 \%$ for $\mathrm{MB}$ and $22 \%$ for $\mathrm{RhB}$.

In terms of lifetime, the B-CSGOM was more stable in all operating situations and produced better results. This indicates that the properties of the membrane precursor were responsible for most of the dye removal capacity in the carbon-based membrane bioreactors operated under identical conditions. Thus, in addition to providing the required energy for microbial growth, it works as a redox mediator by enhancing the electron transfer to the azo, hydrogen and other bonds of the dye molecule, thereby breaking the bonds to achieve the effective biodegradation of dyes [17].

However, regardless of the flux, the difference of the decolorization between B-CSCM and B-CSGOM was rather low for ADM and MB, whereas this was indeed noticeable for RhB. In general, the color removal efficiency for ADM (96-94\% in B-CSGOM and $95-88 \%$ in B-CSCM), MB (98\% in B-CSGOM and $96 \%$ in B-CSCM) and RhB (94-84\% in B-CSGOM and $79-66 \%$ in B-CSCM) was remarkably steady at low permeate flux, $0.05 \mathrm{~L} \cdot \mathrm{m}^{-2} \cdot \mathrm{h}^{-1}$, as illustrated by Figure 8, with no significant steady changes found when the feed concentrations were first increased up to $75 \mathrm{mg} \cdot \mathrm{L}^{-1}$ and then up to $100 \mathrm{mg} \cdot \mathrm{L}^{-1}$. The results obtained were mostly consistent and, in some cases, showed much better decolorization performance than those using conventional adsorption, photocatalysis, filtration and bacterial treatment processes for decolorizing the dye mixture, Methylene Blue and Rhodamine Blue dye solutions $[2,16,54]$. It must be noted that dye removal levels reached here were similar to those obtained using nanofiltration coupled with wet oxidation, PVDF membrane sensitized nano zeolite, MBR with electrocoagulation and Ag/Pd-loaded $\mathrm{ZnO}$ nanofiber membrane with UV irradiation, where over $85 \%$ of color removal [55-58] was shown. Some other membrane-based dye removal treatment processes, such as nanofiltration under unstirred batch and continuous crossflow mode [59] and activated carbon-PVDF Blend Membrane [60] showed the limitations and were capable of decolorizing just up to $70 \%$. 

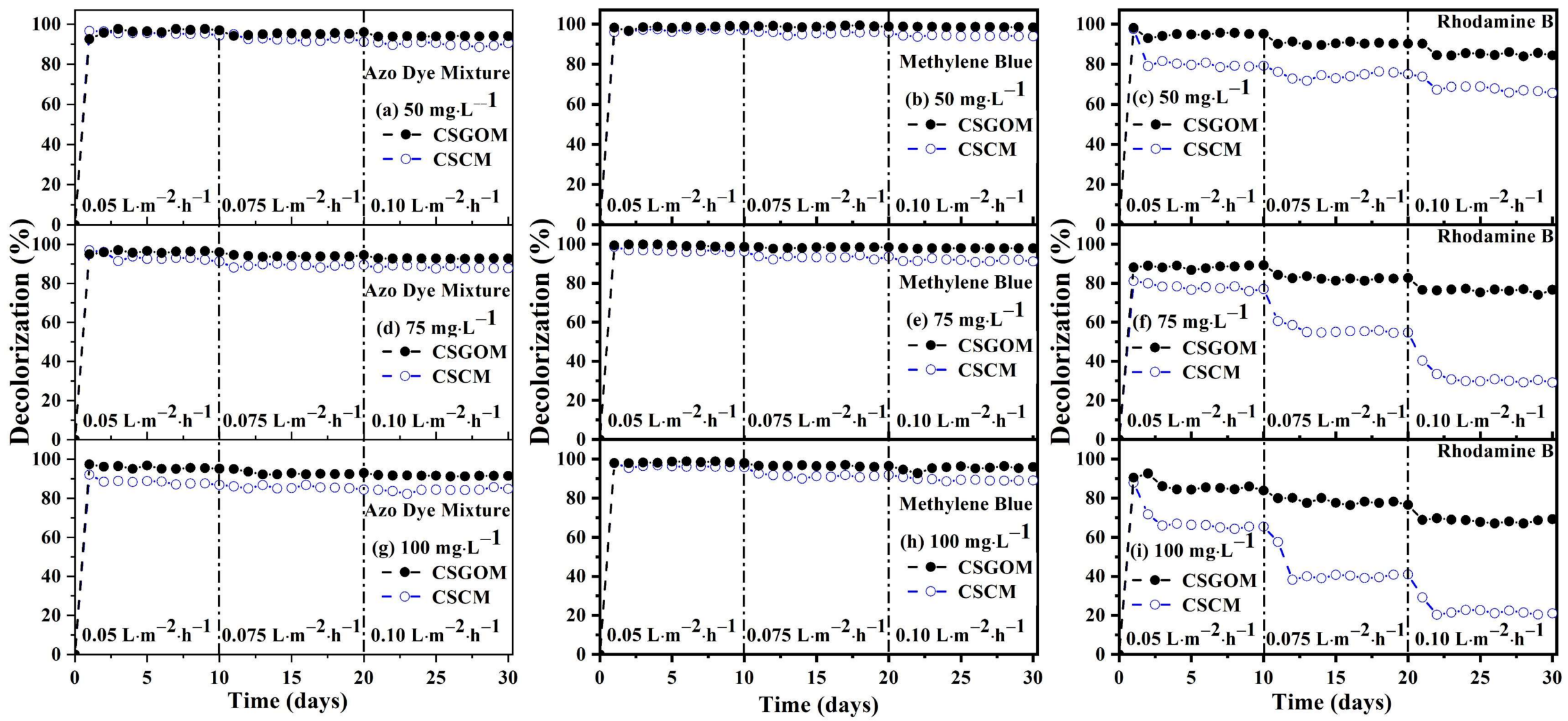

Figure 8. Anaerobic decolorization of the Azo dye mixture, Methylene Blue, and Rhodamine B dyes at various concentrations and fluxes; (a-c) 50 mg. $\mathrm{L}^{-1}$ (d-f) $75 \mathrm{mg} \cdot \mathrm{L}^{-1}$ and $(\mathbf{g}-\mathbf{i}) 100 \mathrm{mg} \cdot \mathrm{L}^{-1}$ at $37^{\circ} \mathrm{C}$. CSCM: $10 \%$ wt. of Matrimid and CSGOM: $1 \mathrm{mg} \cdot \mathrm{mL}^{-1}$ of GO. 
During the biodecolorization process, the biomass load was sufficient to form active biofilms to ensure complete biodegradation of the dyes, even with the short contact times associated to one-pass direct filtration operation. Even so, low permeate flow allowed the dye molecules to interact sufficiently with the microorganisms, stimulating the effective biodecolorization rate [61,62], though higher permeate flux is of course detrimental for achieving high biodegradation $[63,64]$. Therefore, the increase of the permeate flux from 0.05 to $0.075 \mathrm{~L} \cdot \mathrm{m}^{-2} \cdot \mathrm{h}^{-1}$ and, finally, to $0.1 \mathrm{~L} \cdot \mathrm{m}^{-2} \cdot \mathrm{h}^{-1}$ provides declining decolorization of ADM, MB and RhB dye solutions up to $94 \%, 98 \%$ and $85 \%$, respectively, in B-CSGOM, which are more evident for B-CSCM, where they decreased to $89 \%$ for ADM, $94 \%$ for MB and $66 \%$ for the most reluctant RhB.

Increased feed concentration of dye molecules introduced more reactive groups into the anaerobic bioreactor, as did increasing permeate flux. In such conditions, the excess load of functional groups causes an inadequate biomass to dye ratio $[16,63]$. Therefore, some dye molecules escape the membrane reactor without undergoing adequate biodegradation. Additionally, the toxicity effect of the dye molecules affects active sites in the biofilm, reducing the decolorization effectiveness of the membrane reactor. These features were reflected in Figure $8 \mathrm{a}-\mathrm{c}$, where the color removal for each of the dye solutions and compact bioreactors declined as the initial feed concentration or permeate flux increased so the load to the anaerobic biodegradation system rises. The feed concentration was first increased from 50 to $75 \mathrm{mg} \cdot \mathrm{L}^{-1}$ and, later, to $100 \mathrm{mg} \cdot \mathrm{L}^{-1}$, in B-CSGOM; accordingly, the decolorization rate for the ADM, MB and RhB solutions was reduced to $91 \%, 96 \%$ and $67 \%$, respectively. Whereas for B-CSCM, it was decreased to $84 \%$ for ADM, $88 \%$ for MB and $22 \%$ for RhB. In an earlier investigation, the color removal rate of individually administered AO7, RB5 and BD71 solutions was respectively $34-58 \%$ in B-CSCM and $86-97 \%$ in B-CSGOM $[21,26]$.

For the azo dye mixture, this study achieved a decolorization up to $90 \%$ and $94 \%$ for B-CSCM and B-CSGOM, respectively. In the instance of ADM, the mixed solution exhibited a synergic effect, which increased the biodecolorization of the ADM compared to the individual dye. Additionally, the mixture of numerous azo dyes and their metabolic products boosts the carbon sources or food available to the microbe that improves the bioreduction of dye molecules. B-CSGOM, on the other hand, performs significantly better than B-CSCM because its GO layer is more conductive than the CSCM carbon layer to escalate the biodegradation performance.

As can be seen, color removal for the MB exhibited less sensitivity to the bioreactor configuration and operating conditions. This treatment behavior can be influenced by the factors that dye removal efficacy varies, such as dye structure with different bonds and functional groups, dye concentration, external carbon and nitrogen sources, electron donor, redox mediator, food to microorganism ratio, and the microorganism growth $[65,66]$. Increasing feed concentration of ADM in the bioreactor means more azo bonds but also that more other functional groups were entered into the biodegradation system. On the contrary, the rate of biodecolorization of the RhB dye solution was the lowest in all cases. $\mathrm{RhB}$ molecules are coalesced by nature and easily stick into the pores or the biofilm. As a result, activity and development of the microbial were prevented, which reduced the biodegradability performance of RhB. The reason for the two-and-a-half-fold higher rate of RhB decolorization in B-CSGOM in comparison to B-CSCM should be assigned to the best capacity of graphene oxide to transfer electrons, which is critical for this more structurally complex dye.

\section{Conclusions}

In this study, the feasibility of two carbon-based membranes integrated with an anaerobic process proved to be efficient for treating several dye solutions. The systems were tested to decolorize azo dye mixtures made of monoazo Acid Orange 7, diazo Reactive Black 5 and triazo Direct Blue 71 dyes. In addition, they were also tested over the phenothiazine, Methylene Blue and the sticky fluorescence Rhodamine B (RhB). 
It was found that the enhanced electron transfer mechanism of graphene oxide in the CSGOM unit seems to be superior to the carbonaceous layer present in the CSCM configuration. Additionally, this nanoscaled GO layer appears to stimulate the establishment of stable biofilms and to retain better dye molecules and biodegradation derived compounds.

Under the lowest feed concentration $\left(50 \mathrm{mg} \cdot \mathrm{L}^{-1}\right)$ and permeate flux $\left(0.05 \mathrm{~L} \cdot \mathrm{m}^{-2} \cdot \mathrm{h}^{-1}\right)$, maximum decolorization of the dye solutions in CSGOM bioreactor was 96\% for ADM, $98 \%$ for $\mathrm{MB}$ and $94 \%$ for $\mathrm{RhB}$; in turn, for B-CSCM, it was $89 \%, 94 \%$ and $66 \%$. In response to increasing feed and flux, after 30 days of operation, the decolorization rate of ADM and MB was only $8-12 \%$ and $2-5 \%$ lower in B-CSCM and B-CSGOM, respectively. RhB was demonstrated to be more reluctant, so the decolorization lowered up to $67 \%$ in B-CSGOM and only $26 \%$ in B-CSCM for the more unfavorable conditions, higher feed concentration and flux.

The present investigation shows that compact graphene oxide membrane-based anaerobic biosystems can be successfully applied for the decolorization of a wide variety of isolate or mixed dye molecules.

The definition of the kinetics describing the anaerobic bioreduction of azo dyes is highly needed in order to optimize the decolorization performance so the implementation at a large scale can be lowered. In this sense, operation at higher permeate flux or availability of more conductive membranes would be desirable, too.

Author Contributions: Conceptualization, J.F. and M.S.A.A.; investigation, M.S.A.A.; writingoriginal draft preparation, J.F. and M.S.A.A.; writing-review and editing, J.F. and M.S.A.A.; resources, F.S., J.G., A.F. (Azael Fabregat), A.F. (Agustin Fortuny) and J.F.; validation, F.S., J.G., A.F. (Azael Fabregat) and A.F. (Agustin Fortuny); supervision, J.F. All authors have read and agreed to the published version of the manuscript.

Funding: This project has been supported by the European Union's Horizon 2020 research and innovation programme under the Marie Skłodowska-Curie grant agreement No. 713679 and by the Universitat Rovira i Virgili (URV), contract 2017MFP-COFUND-18. This article was possible thanks to the grant RTI2018-096467-B-I00 funded by MCIN/AEI/10.13039/501100011033 and "ERDF A way of making Europe". The authors research group is recognized by the Comissionat per a Universitats i Recerca, DIUE de la Generalitat de Catalunya (2017 SGR 396), and supported by the Universitat Rovira i Virgili (2021PFR-URV-87).

Institutional Review Board Statement: Not applicable.

Informed Consent Statement: Not applicable.

Data Availability Statement: The data presented in this study are available on request from the corresponding author.

Conflicts of Interest: The authors declare no conflict of interest.

\section{References}

1. Adeel, S.; Saeed, M.; Shahzad, M.; Haq, A.; Muneer, M.; Younas, M. Decolorization of Rhodamine B Dye in Aqueous Medium. Chiang Mai J. Sci. 2015, 42, 730-744.

2. Gupta, V.K.; Khamparia, S.; Tyagi, I.; Jaspal, D.; Malviya, A. Decolorization of mixture of dyes: A critical review. Glob. J. Environ. Sci. Manag. 2015, 1, 71-94. [CrossRef]

3. Holkar, C.R.; Jadhav, A.J.; Pinjari, D.V.; Mahamuni, N.M.; Pandit, A.B. A critical review on textile wastewater treatments: Possible approaches. J. Environ. Manag. 2016, 182, 351-366. [CrossRef]

4. Elshahawy, M.F.; Mahmoud, G.A.; Raafat, A.I.; Ali, A.E.-H.; Soliman, E.S.A. Fabrication of $\mathrm{TiO}_{2}$ Reduced Graphene Oxide Based Nanocomposites for Effective of Photocatalytic Decolorization of Dye Effluent. J. Inorg. Organomet. Polym. Mater. 2020, 30, 2720-2735. [CrossRef]

5. Pavithra, K.G.; Jaikumar, V. Removal of colorants from wastewater: A review on sources and treatment strategies. J. Ind. Eng. Chem. 2019, 75, 1-19. [CrossRef]

6. Ledakowicz, S.; Paździor, K. Recent Achievements in Dyes Removal Focused on Advanced Oxidation Processes Integrated with Biological Methods. Molecules 2021, 26, 870. [CrossRef] 
7. Wang, Y.; Pan, J.; Li, Y.; Zhang, P.; Li, M.; Zheng, H.; Zhang, X.; Li, H.; Du, Q. Methylene blue adsorption by activated carbon, nickel alginate/activated carbon aerogel, and nickel alginate/graphene oxide aerogel: A comparison study. J. Mater. Res. Technol. 2020, 9, 12443-12460. [CrossRef]

8. Uddin, M.J.; Islam, M.A.; Haque, S.A.; Hasan, S.; Amin, M.S.A.; Rahman, M.M. Preparation of nanostructured TiO2-based photocatalyst by controlling the calcining temperature and $\mathrm{pH}$. Int. Nano Lett. 2012, 2, 19. [CrossRef]

9. Lellis, B.; Fávaro-Polonio, C.Z.; Pamphile, J.A.; Polonio, J.C. Effects of textile dyes on health and the environment and bioremediation potential of living organisms. Biotechnol. Res. Innov. 2019, 3, 275-290. [CrossRef]

10. Hassan, M.M.; Carr, C.M. A critical review on recent advancements of the removal of reactive dyes from dyehouse effluent by ion-exchange adsorbents. Chemosphere 2018, 209, 201-219. [CrossRef] [PubMed]

11. Caprarescu, S.; Miron, A.R.; Purcar, V.; Radu, A.-L.; Sarbu, A.; Ion-Ebrasu, D.; Atanase, L.-I.; Ghiurea, M. Efficient removal of Indigo Carmine dye by a separation process. Water Sci. Technol. 2016, 74, 2462-2473. [CrossRef]

12. Modrogan, C.; Căprărescu, S.; Dăncilă, A.M.; Orbuleț, O.D.; Grumezescu, A.M.; Purcar, V.; Radițoiu, V.; Fierascu, R.C. Modified Composite Based on Magnetite and Polyvinyl Alcohol: Synthesis, Characterization, and Degradation Studies of the Methyl Orange Dye from Synthetic Wastewater. Polymers 2021, 13, 3911. [CrossRef] [PubMed]

13. Islam, M.A.; Amin, M.S.A.; Hoinkis, J. Optimal design of an activated sludge plant: Theoretical analysis. Appl. Water Sci. 2013, 3, 375-386. [CrossRef]

14. Obotey Ezugbe, E.; Rathilal, S. Membrane Technologies in Wastewater Treatment: A Review. Membranes 2020, 10, 89. [CrossRef]

15. García-Martínez, Y.; Chirinos, J.; Bengoa, C.; Stüber, F.; Font, J.; Fortuny, A.; Fabregat, A. Fast Aqueous Biodegradation of Highly-Volatile Organic Compounds in a Novel Anaerobic Reaction Setup. Environments 2018, 5, 115. [CrossRef]

16. Tao, P.; Xu, Y.; Song, C.; Yin, Y.; Yang, Z.; Wen, S.; Wang, S.; Liu, H.; Li, S.; Li, C.; et al. A novel strategy for the removal of rhodamine $\mathrm{B}(\mathrm{RhB})$ dye from wastewater by coal-based carbon membranes coupled with the electric field. Sep. Purif. Technol. 2017, 179, 175-183. [CrossRef]

17. Xiao, X.; Li, T.-T.; Lu, X.-R.; Feng, X.-L.; Han, X.; Li, W.-W.; Li, Q.; Yu, H.-Q. A simple method for assaying anaerobic biodegradation of dyes. Bioresour. Technol. 2018, 251, 204-209. [CrossRef] [PubMed]

18. Ion-Ebrasu, D.; Pollet, B.G.; Spinu-Zaulet, A.; Soare, A.; Carcadea, E.; Varlam, M.; Caprarescu, S. Graphene modified fluorinated cation-exchange membranes for proton exchange membrane water electrolysis. Int. J. Hydrog. Energy 2019, 44, 10190-10196. [CrossRef]

19. Ion-Ebrasu, D.; Pollet, B.G.; Caprarescu, S.; Chitu, A.; Trusca, R.; Niculescu, V.; Gabor, R.; Carcadea, E.; Varlam, M.; Vasile, B.S. Graphene inclusion effect on anion-exchange membranes properties for alkaline water electrolyzers. Int. J. Hydrog. Energy 2020, 45, 17057-17066. [CrossRef]

20. Pan, Z.; Song, C.; Li, L.; Wang, H.; Pan, Y.; Wang, C.; Li, J.; Wang, T.; Feng, X. Membrane technology coupled with electrochemical advanced oxidation processes for organic wastewater treatment: Recent advances and future prospects. Chem. Eng. J. 2019, 376, 120909. [CrossRef]

21. Amin, M.S.A.; Stüber, F.; Giralt, J.; Fortuny, A.; Fabregat, A.; Font, J. Comparative Anaerobic Decolorization of Azo Dyes by Carbon-Based Membrane Bioreactor. Water 2021, 13, 1060. [CrossRef]

22. Khraisheh, M.; Elhenawy, S.; AlMomani, F.; Al-Ghouti, M.; Hassan, M.K.; Hameed, B.H. Recent Progress on Nanomaterial-Based Membranes for Water Treatment. Membranes 2021, 11, 995. [CrossRef] [PubMed]

23. Isaeva, V.I.; Vedenyapina, M.D.; Kurmysheva, A.Y.; Weichgrebe, D.; Nair, R.R.; Nguyen, N.P.; Kustov, L.M. Modern Carbon-Based Materials for Adsorptive Removal of Organic and Inorganic Pollutants from Water and Wastewater. Molecules 2021, $26,6628$. [CrossRef]

24. Manawi, Y.; Kochkodan, V.; Hussein, M.A.; Khaleel, M.A.; Khraisheh, M.; Hilal, N. Can carbon-based nanomaterials revolutionize membrane fabrication for water treatment and desalination? Desalination 2016, 391, 69-88. [CrossRef]

25. Perreault, F.; Fonseca de Faria, A.; Elimelech, M. Environmental applications of graphene-based nanomaterials. Chem. Soc. Rev. 2015, 44, 5861-5896. [CrossRef] [PubMed]

26. Amin, M.S.A.; Stüber, F.; Giralt, J.; Fortuny, A.; Fabregat, A.; Font, J. Ceramic-supported graphene oxide membrane bioreactor for the anaerobic decolorization of azo dyes. J. Water Process Eng. 2022, 45, 102499. [CrossRef]

27. Giménez-Pérez, A.; Bikkarolla, S.K.; Benson, J.; Bengoa, C.; Stüber, F.; Fortuny, A.; Fabregat, A.; Font, J.; Papakonstantinou, P. Synthesis of $\mathrm{N}$-doped and non-doped partially oxidised graphene membranes supported over ceramic materials. J. Mater. Sci. 2016, 51, 8346-8360. [CrossRef]

28. Chen, A.; Yang, B.; Zhou, Y.; Sun, Y.; Ding, C. Effects of azo dye on simultaneous biological removal of azo dye and nutrients in wastewater. R. Soc. Open Sci. 2018, 5, 180795. [CrossRef] [PubMed]

29. El Bouraie, M.; El Din, W.S. Biodegradation of Reactive Black 5 by Aeromonas hydrophila strain isolated from dye-contaminated textile wastewater. Sustain. Environ. Res. 2016, 26, 209-216. [CrossRef]

30. Sazali, N.; Salleh, W.N.W.; Md Nordin, N.A.H.; Harun, Z.; Ismail, A.F. Matrimid-based carbon tubular membranes: The effect of the polymer composition. J. Appl. Polym. Sci. 2015, 132, 42394. [CrossRef]

31. Dohade, M. Incorporation of carbon nanofibers into a Matrimid polymer matrix: Effects on the gas permeability and selectivity properties. J. Appl. Polym. Sci. 2018, 135, 46019. [CrossRef]

32. Sazali, N.; Salleh, W.N.W.; Nordin, N.A.H.M.; Ismail, A.F. Matrimid-based carbon tubular membrane: Effect of carbonization environment. J. Ind. Eng. Chem. 2015, 32, 167-171. [CrossRef] 
33. Rattana; Chaiyakun, S.; Witit-anun, N.; Nuntawong, N.; Chindaudom, P.; Oaew, S.; Kedkeaw, C.; Limsuwan, P. Preparation and characterization of graphene oxide nanosheets. Procedia Eng. 2012, 32, 759-764. [CrossRef]

34. Wang, J.; Zhang, P.; Liang, B.; Liu, Y.; Xu, T.; Wang, L.; Cao, B.; Pan, K. Graphene Oxide as an Effective Barrier on a Porous Nanofibrous Membrane for Water Treatment. ACS Appl. Mater. Interfaces 2016, 8, 6211-6218. [CrossRef] [PubMed]

35. Luo, Q.; Cai, Q.; Li, X.; Pan, Z.; Li, Y.; Chen, X.; Yan, Q. Preparation and characterization of ZrO2/TiO2 composite photocatalytic film by micro-arc oxidation. Trans. Nonferrous Met. Soc. China 2013, 23, 2945-2950. [CrossRef]

36. Ruppert, A.M.; Agulhon, P.; Grams, J.; Wąchała, M.; Wojciechowska, J.; Świerczyński, D.; Cacciaguerra, T.; Tanchoux, N.; Quignard, F. Synthesis of TiO2-ZrO2 Mixed Oxides via the Alginate Route: Application in the Ru Catalytic Hydrogenation of Levulinic Acid to Gamma-Valerolactone. Energies 2019, 12, 4706. [CrossRef]

37. Ismail, N.H.; Salleh, W.N.W.; Sazali, N.; Ismail, A.F. Development and characterization of disk supported carbon membrane prepared by one-step coating-carbonization cycle. J. Ind. Eng. Chem. 2018, 57, 313-321. [CrossRef]

38. Johra, F.T.; Lee, J.-W.; Jung, W.-G. Facile and safe graphene preparation on solution based platform. J. Ind. Eng. Chem. 2014, 20, 2883-2887. [CrossRef]

39. Bikkarolla, S.K.; Cumpson, P.; Joseph, P.; Papakonstantinou, P. Oxygen reduction reaction by electrochemically reduced graphene oxide. Faraday Discuss. 2014, 173, 415-428. [CrossRef]

40. Thema, F.T.; Moloto, M.J.; Dikio, E.D.; Nyangiwe, N.N.; Kotsedi, L.; Maaza, M.; Khenfouch, M. Synthesis and Characterization of Graphene Thin Films by Chemical Reduction of Exfoliated and Intercalated Graphite Oxide. J. Chem. 2013, $2013,150536$. [CrossRef]

41. Ismail, N.H.; Salleh, W.N.W.; Sazali, N.; Ismail, A.F.; Yusof, N.; Aziz, F. Disk supported carbon membrane via spray coating method: Effect of carbonization temperature and atmosphere. Sep. Purif. Technol. 2018, 195, 295-304. [CrossRef]

42. Wu, S.; Zhang, B.; Liu, Y.; Suo, X.; Li, H. Influence of surface topography on bacterial adhesion: A Review. Biointerphases 2018, 13, 060801. [CrossRef] [PubMed]

43. Oder, M.; Arlič, M.; Bohinc, K.; Fink, R. Escherichia coli biofilm formation and dispersion under hydrodynamic conditions on metal surfaces. Int. J. Environ. Health Res. 2018, 28, 55-63. [CrossRef] [PubMed]

44. Niu, F.; Huang, M.; Cai, T.; Meng, L. Effect of Membrane Thickness on Properties of FO Membranes with Nanofibrous Substrate. IOP Conf. Ser. Earth Environ. Sci. 2018, 170, 052005. [CrossRef]

45. Ismail, N.H.; Salleh, W.N.W.; Sazali, N.; Ismail, A.F. Effect of intermediate layer on gas separation performance of disk supported carbon membrane. Sep. Sci. Technol. 2017, 52, 2137-2149. [CrossRef]

46. Yang, M.; Zhao, C.; Zhang, S.; Li, P.; Hou, D. Preparation of graphene oxide modified poly(m-phenylene isophthalamide) nanofiltration membrane with improved water flux and antifouling property. Appl. Surf. Sci. 2016, 394, 149-159. [CrossRef]

47. Xu, K.; Feng, B.; Zhou, C.; Huang, A. Synthesis of highly stable graphene oxide membranes on polydopamine functionalized supports for seawater desalination. Chem. Eng. Sci. 2016, 146, 159-165. [CrossRef]

48. Lou, Y.; Liu, G.; Liu, S.; Shen, J.; Jin, W. A facile way to prepare ceramic-supported graphene oxide composite membrane via silane-graft modification. Appl. Surf. Sci. 2014, 307, 631-637. [CrossRef]

49. Yaseen, D.A.; Scholz, M. Textile dye wastewater characteristics and constituents of synthetic effluents: A critical review. Int. J. Environ. Sci. Technol. 2019, 16, 1193-1226. [CrossRef]

50. Xu, N.; Guo, D.; Xiao, C. Fe/Mn oxide decorated polyacrylonitrile hollow fiber membrane as heterogeneous Fenton reactor for methylene blue decolorization. J. Appl. Polym. Sci. 2019, 136, 48217. [CrossRef]

51. Ming, J.; Sun, D.; Wei, J.; Chen, X.; Zheng, N. Adhesion of Bacteria to a Graphene Oxide Film. ACS Appl. Biol. Mater. 2020, 3 , 704-712. [CrossRef] [PubMed]

52. Chen, H.; Gao, D.; Wang, B.; Zhao, R.; Guan, M.; Zheng, L.-; Zhou, X.; Chai, Z.; Feng, W. Graphene oxide as an anaerobic membrane scaffold for the enhancement of B. adolescentis proliferation and antagonistic effects against pathogens E. coli and $S$ aureus. Nanotechnology 2014, 25, 165101. [CrossRef]

53. Mezohegyi, G.; Bengoa, C.; Stuber, F.; Font, J.; Fabregat, A.; Fortuny, A. Novel bioreactor design for decolourisation of azo dye effluents. Chem. Eng. J. 2008, 143, 293-298. [CrossRef]

54. Hashemi Salehi, M.; Yousefi, M.; Hekmati, M.; Balali, E. Application of palladium nanoparticle-decorated Artemisia abrotanum extract-modified graphene oxide for highly active catalytic reduction of methylene blue, methyl orange and rhodamine B. Appl. Organomet. Chem. 2019, 33, e5123. [CrossRef]

55. Dhale, A.D.; Mahajani, V.V. Studies in treatment of disperse dye waste: Membrane-wet oxidation process. Waste Manag. 2000, 20, 85-92. [CrossRef]

56. Zhang, X.; Hu, Y.; Yang, W.; Feng, M. Ag-loaded and Pd-loaded ZnO nanofiber membranes: Preparation via electrospinning and application in photocatalytic antibacterial and dye degradation. Appl. Nanosci. 2021, in press. [CrossRef]

57. Ismail, A.M.; Menazea, A.A.; Ali, H. Selective adsorption of cationic azo dyes onto zeolite nanorod-based membranes prepared via laser ablation. J. Mater. Sci. Mater. Electron. 2021, 32, 19352-19367. [CrossRef]

58. Ravadelli, M.; da Costa, R.E.; Lobo-Recio, M.A.; Akaboci, T.R.V.; Bassin, J.P.; Lapolli, F.R.; Belli, T.J. Anoxic/oxic membrane bioreactor assisted by electrocoagulation for the treatment of azo-dye containing wastewater. J. Environ. Chem. Eng. 2021, 9, 105286. [CrossRef]

59. Chakraborty, S.; Purkait, M.K.; DasGupta, S.; De, S.; Basu, J.K. Nanofiltration of textile plant effluent for color removal and reduction in COD. Sep. Purif. Technol. 2003, 31, 141-151. [CrossRef] 
60. Ye, Q.; Li, J.; Han, Q.; Xu, M.; Jiang, L.; Yan, B. Preparation of Activated Carbon-PVDF Blend Membrane and Its Effect on the Decolorization of Azo Dyes. IOP Conf. Ser. Earth Environ. Sci. 2021, 793, 012012. [CrossRef]

61. Rahimi, M.; Aghel, B.; Sadeghi, M.; Ahmadi, M. Using Y-shaped microreactor for continuous decolorization of an Azo dye. Desalin. Water Treat. 2014, 52, 5513-5519. [CrossRef]

62. Ewida, A.Y.I.; El-Sesy, M.E.; Abou Zeid, A. Complete degradation of azo dye acid red 337 by Bacillus megaterium KY848339.1 isolated from textile wastewater. Water Sci. 2019, 33, 154-161. [CrossRef]

63. Li, Q.; Tang, X.; Sun, Y.; Wang, Y.; Long, Y.; Jiang, J.; Xu, H. Removal of Rhodamine B from wastewater by modified Volvariella volvacea: Batch and column study. RSC Adv. 2015, 5, 25337-25347. [CrossRef]

64. Popli, S.; Patel, U.D. Destruction of azo dyes by anaerobic-aerobic sequential biological treatment: A review. Int. J. Environ. Sci. Technol. 2015, 12, 405-420. [CrossRef]

65. Khan, R.; Bhawana, P.; Fulekar, M.H. Microbial decolorization and degradation of synthetic dyes: A review. Rev. Environ. Sci. Bio Technol. 2013, 12, 75-97. [CrossRef]

66. Solís, M.; Solís, A.; Pérez, H.I.; Manjarrez, N.; Flores, M. Microbial decolouration of azo dyes: A review. Process Biochem. 2012, 47, 1723-1748. [CrossRef] 